\title{
PUBLIC ATTITUDES AND ENVIRONMENTAL IMPACTS OF WIND FARMS: A REVIEW
}

\section{KARYDIS M.}

\author{
Department of Marine Sciences \\ University of the Aegean \\ 81100 Mytilene, Greece
}

*to whom all correspondence should be addressed: e-mail: mkar@aegean.gr

\begin{abstract}
The promotion of renewable sources for electricity production, independent of carbon fuels and nuclear power, is a priority in the energy policy of many countries all over the world. The European Union has launched an ambitious program to increase the contribution of energy production from wind turbines; the aim set for the year 2020 is that wind power should account for $31 \%$ of EU's current target regarding $20 \%$ reductions of carbon dioxide. This policy is favored by the fact that wind energy production cost is nowadays competitive in many cases to the cost of electricity produced from conventional non-renewable sources. However, there is a conflict concerning public attitudes: although the public in general is in favor of renewable energy sources including wind, there is usually very strong opposition by local people living in neighboring areas of wind farm developments that is attitudes toward wind power are to a large extent different from attitudes toward wind farms. It is also interesting that negative public opinion is rather high during the planning stage and significantly lower during the implementation stage. In addition, there are impacts on landscape aesthetic, human health as well as ecological impact on the flora and fauna, although compared to environmental impact from conventional energy sources, the environmental impact caused by wind turbines is relatively minor. Recent developments of offshore wind farms seemed to avoid people's negative attitudes and soften public resistance and hostility against wind power energy but these expectations were rather optimistic. Opposition due to seascape aesthetic spoiling is as strong even for the marine environment. The impact on marine life and particularly on sea mammals due to noise and vibrations need to be further investigated. Existing activities such as navigation, fishing and recreational activities should not be hindered during site selection and planning. In the present work public attitudes and impacts on human health as well as impacts on landscape and ecosystem level, both terrestrial and marine, are reviewed and discussed.
\end{abstract}

KEYWORDS: Renewable Energy; Landscape; Offshore Wind Energy; Public Participation; Noise; Ecological Impact; Impact on Marine Life.

\section{INTRODUCTION}

Many developed countries including European Union States, United States and Japan have developed a long term plan on converting from the use of non-renewable power energy sources such as oil, coal and uranium to renewable energy sources which are wind, solar energy and biomass (Soderholm et al., 2007). The state support for energy production from renewable sources has been increased greatly over the last twenty years (Nadai and Van der Horst, 2010). Recently at least 73 countries have adopted green policy for power generation (REN21, 2009). This is because electricity production from renewable sources became feasible, mainly for three reasons (a) there is a day-to-day improvement on renewable energy technology (b) oil prices follow an upward trend over the last three decades and (c) the carbon dioxide emission policy introduced carbon tax paid for mineral fuels. In addition, unlike most coal or oil fuel facilities, renewable energy installations can be 
decentralized and located in the countryside where other industries are rare (Anon, 2010). They can provide economic benefits in areas characterized by a poor agricultural sector or seasonal tourism. European's Union objectives to increase the share of renewable electric power; it was $22 \%$ in 2010 and it is expected to be $30 \%$ in the year 2020 (EC, 2001). Among the renewable energy sources wind power received serious attention after the 70 s due to crude oil high prices but fast growth did not start before 90s (Warren et al., 2005). It has been reported (Ackerman and Soder, 2002) that wind power capacity doubles every three years followed by an impressive decrease in generating costs; nowadays wind power prices are, in some cases characterized by good wind resources, competitive with power produced from conventional (carbon and nuclear) sources.

Although wind power seems to be one of the most attractive renewable sources in terms of production cost and environmental impact, there are many reservations by the public due to a combination of attitudes and impacts (Krause, 2001; Etherington, 2010). The public attitude is characterized by the NIMBY (Not-In-My-BackYard) syndrome. Public arguments like "no to wind turbines in the mountains" or "stop the spinning madness" have been reported several times (Soderholm et al., 2007; Etherington, 2010). The usual reasons given against wind mill installations are changes on the landscape character, impacts on bird life, noise and land devaluation (Krause, 2001; Brenner, 1993; Alves-Perreira and Castello-Bianco, 2007a). Wind power stations cannot be part of the natural environment due to the industrial character and appearance. In spite of that, governments and investors are mainly interested in the economic aspect of wind farms. They sacrifice the natural environment at a local scale to respond to the increased demand for electricity. Arguments of the type that "wind turbines are natural elements in the landscape" have been reported (Danish Wind Industry Association Website). However, an article published in The Times in 2003 criticizes the sacrifice of the landscape by the British Authorities: "The Government's thesis that the countryside of upland and coastal Britain is worth sacrificing to save the planet is an insult to science, economics and politics. But the greatest insult is to aesthetics. The trouble is that aesthetics has no way of answering back" (Simon Jenkins, The Times, 24 October, 2003).

Research on wildlife from wind farms has also been performed. The impact of wind mills on the bird fauna has been studied in many countries (Brenner, 1993). Bats seem to be attracted by rotating blades and being buffeted by wake vortices; air pressure fluctuations cause lung bursting (Etherington, 2010). It has been found that the indigenous bird fauna is more resistant than the emigrating bird fauna. The noise from wind generators causes problems when the wind farm is located near residential areas. Impacts on human health from the generator noise have been studied (Todd et al., 2008). The tendency nowadays is to install wind generators in the marine environment far from residential areas and delicate landscapes. There is still limited knowledge on the impact on marine organisms although indications of the impact of noise on some groups of marine organisms such as crustacea (Nowacek et al., 2007), seabirds (Gathe and Huppop, 2004) and porpoises (Carstensen et al., 2006) have been published.

The present work is a review on public attitudes and environmental impacts by land based and offshore wind installations.

\section{WIND POWER ENERGY POLICY IN THE EUROPEAN UNION}

Many countries since the 80 s have accepted the need towards a reduction of greenhouse gas emissions. The Montreal Protocol on reduction of greenhouse gases was signed in 1987 and amended in 1990. Governments have undertaken the commitment to reduce production and consumption of chemical compounds that weaken the stratospheric ozone layer; some of them also contribute to global warming (Middleton, 2008). An effort more focused on carbon dioxide was initiated by a global forum in the UN Framework Convention on Climate Change (UNFCCC). The Convention, signed in 1992 by 150 countries, was enforced in March 1994. The signatory parties accepted to reduce carbon dioxide emissions to 1990 levels on a voluntary basis. Legally binding for carbon dioxide reduction was made in 1997 with the Kyoto Protocol within the framework of climatic changes (Birnie et al., 2009). Kyoto Protocol was ratified in 2005. The aim of the Protocol was to reduce greenhouse emissions by $5 \%$ per year accepting as background values the emissions of each country in 1990. Japan and USA were among the countries with the highest carbon dioxide emissions that signed the Kyoto Protocol. However, the USA and Australia have not signed the Protocol up to date. The Kyoto Protocol entered in force in February 2005. 
Following the Kyoto Protocol EU passed in 2001 a Directive "on the promotion of electricity produced from renewable energy sources in the internal electricity market" (EC, 2001a). The EU's commitment was to reduce emissions by $8 \%$ for the EU-15 States as a whole and between 6 and $8 \%$ for the new Member States (EU-12). In 2009 the EU agreed on what is known as "climate energy package"; the objective of this agreement was to produce electricity from renewable sources and reduce emissions by $20 \%$ (referring to 1990 background values) up to the year 2020 (EWEA, 2011a). Using coal, gas and oil for electricity production, the European Commission estimated that these three technologies have an average emission of $696 \mathrm{gCO}_{2} \mathrm{kWh}^{-1}$ by 2010 . The energy production by wind power during 2010 in EU (181 TWh) avoided the production of 126 million tonnes of carbon dioxide. The target for the year 2015 is that EPS could be set around $350 \mathrm{gCO}_{2} \mathrm{kWh}^{-1}$ by 2015 (EWEA, 2011b). According to the figures given above, the EU climate and energy package avoided carbon dioxide emissions by wind energy equivalent to $28 \%$ of the EU's Kyoto commitment for the year 2010 . Estimates by EWEA for the current year (2012) presume that wind power capacity will avoid $35 \%$ of the Kyoto carbon dioxide target. Past and future wind power assessment is presented in Table 1. It is estimated that installed capacity will double in 2020. Approximately the same trend is expected for future wind power production and carbon dioxide avoidance. EWEA has been monitoring wind energy installations since 1985; based on past experience, EWEA presents scenarios for wind energy production referring to years 2020, 2030 and 2050. These scenarios are based on national level policy frameworks and for each target year provides a "baseline" scenario and a "high" scenario. According to the baseline scenario installed capacity in EU in 2020 will be $230 \mathrm{GW}$ and the corresponding production 581 TWh of electricity. The high scenario assumes that wind power is likely to achieve a higher share of the EU's Renewable Energy Directive Target and it is expected that the installed wind power capacity by 2020 can be as high as $265 \mathrm{GW}$, producing 682 TWh of electricity; this figure represents $18.5 \%$ of electricity consumption. Future targets of EU in renewable energy sources are to further reduce emissions in the power sector. The final aim is electricity production to be carbon free by 2050; this allows transfer of carbon dioxide emission rights to other sector where emissions are unavoidable such as agriculture and transport. It is expected that emission reductions by 2050 will be close to a 95\% target (EWEA, 2011b). Figure 1 shows past, present and projected installed wind power capacity, production and avoided emissions in the European Union; it is observed that exponential growth is expected between the current year and 2020.

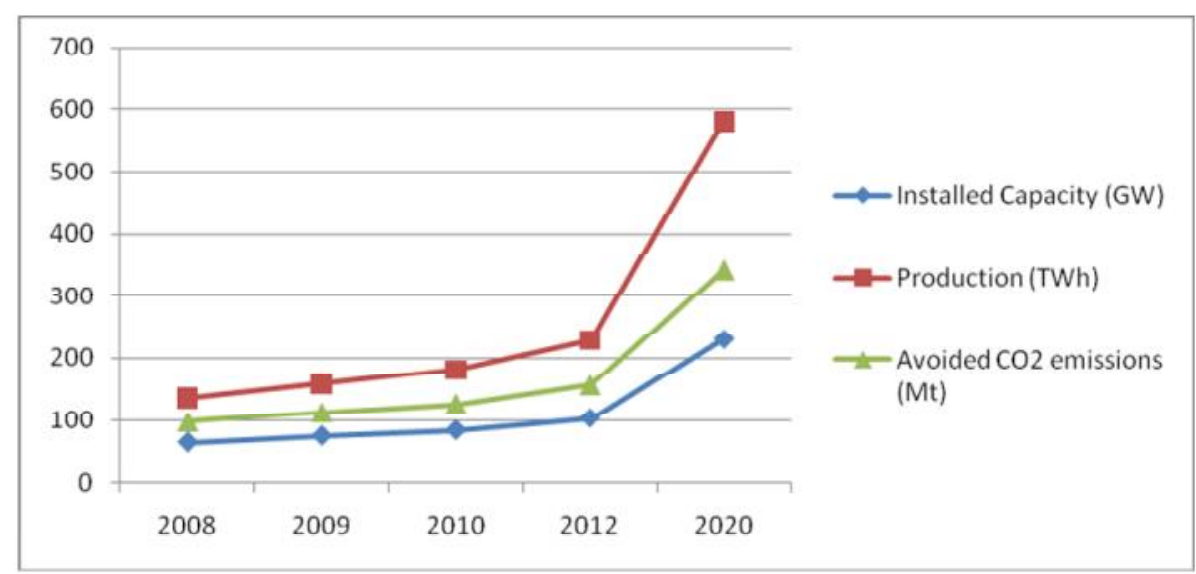

Figure 1. Past, present and projected installed wind power capacity, production and avoided emissions in the European Union (source: EWEA, 2011)

On the other side of the Atlantic Ocean, the US also seems to follow a fast track in electricity production using renewable energy sources. In wind energy the USA has already reached a goal of $16,818 \mathrm{MW}$ in 2007 and the expected wind power capacity by 2030 in the US is expected to be 300,000 MW by wind supply covering $20 \%$ of the nation's electricity (WWEA, 2008). 
Table 1. Arguments against wind farm development

\begin{tabular}{|c|c|c|}
\hline Argument & Impact description & Reference \\
\hline Landscape impacts & $\begin{array}{l}\text { Aesthetic problems } \\
\text { Access to the sight not always } \\
\text { possible Seascape effects }\end{array}$ & $\begin{array}{l}\text { Nadai \& Van der Horst }(2010) \\
\text { Krause }(2001) \\
\text { Gee }(2010) \\
\text { Cowell }(2010)\end{array}$ \\
\hline Noise and Vibrations & $\begin{array}{l}\text { Impact on hearing } \\
\text { Sleep disturbance } \\
\text { Stress on sensitive people }\end{array}$ & $\begin{array}{l}\text { Todd et al. (2008) } \\
\text { Alves-Perreira \& Castelo-Branco } \\
\text { (2007b) } \\
\text { Pedersen \& Persson-Waye, (2007a) } \\
\text { Moller \& Pedersen (2011) } \\
\text { Bakker et al. (2012) } \\
\text { Pedersen et al. (2010) }\end{array}$ \\
\hline $\begin{array}{l}\text { Impact on the } \\
\text { tourism industry }\end{array}$ & $\begin{array}{l}\text { Loss of scenic values } \\
\text { Not access to the sight } \\
\text { "Turbinized" landscapes put off } \\
\text { tourists }\end{array}$ & $\begin{array}{l}\text { VisitScotland (2003) } \\
\text { Etherington }(2010)\end{array}$ \\
\hline $\begin{array}{l}\text { Intermittent } \\
\text { electricity generation }\end{array}$ & $\begin{array}{l}\text { Weather dependent output } \\
\text { Need for coal/gas power } \\
\text { stations as a back up }\end{array}$ & $\begin{array}{l}\text { UKERC }(2006) \\
\text { Etherington }(2010)\end{array}$ \\
\hline $\begin{array}{l}\text { Poor economic } \\
\text { benefits }\end{array}$ & $\begin{array}{l}\text { Very limited job creation } \\
\text { No economic benefits for the } \\
\text { area }\end{array}$ & Calzada-Alvarez et al. (2001) \\
\hline Shadow flicker & $\begin{array}{l}\text { High stress for photosensitive } \\
\text { people }\end{array}$ & $\begin{array}{l}\text { Smedley et al. (2010) } \\
\text { Harding et al. (2008) } \\
\text { Brinckerhoff (2011) }\end{array}$ \\
\hline Ice throw \& Ice shed & $\begin{array}{l}\text { Physical danger to people or } \\
\text { passing vehicles }\end{array}$ & Rideaout et al. (2010) \\
\hline $\begin{array}{l}\text { Low frequency } \\
\text { sound Ultrasound }\end{array}$ & $\begin{array}{l}\text { Evidence of health effects at } \\
\text { levels }>80 \mathrm{~dB}\end{array}$ & Rideaout et al. (2010) \\
\hline Structural failure & $\begin{array}{l}\text { Physical danger to people or } \\
\text { passing vehicles due to blade } \\
\text { or tower cracking and falling }\end{array}$ & Rideaout et al. (2010) \\
\hline
\end{tabular}

PUBLIC ATTITUDES AND PUBLIC PARTICIPATION: CONTROVERSIES AND ACCEPTANCE

It is already well known that new technologies can be implemented only under good socioeconomic acceptance (Wolsink, 2010). In the case of wind power and especially in wind farm siting decisions there is a conflict concerning public acceptance. On one hand there is willingness in society for wind power developments. On the other hand there is strong resistance to any wind power developments by people living near the site. The latter is otherwise known as the NIMBY Syndrome and can be condensed in one short sentence (Bell et al., 2005): "yes wind power is a good idea as long as it is not in my backyard". There is therefore a "gap" between the "collective behavior" initiated by the "concern for the public good" and the "individual behavior" motivated by "self interest". This gap is placed between the support by the general public for wind power developments and a local opposition when the developments take place in their area (Van der Horst, 2007). Three explanations have been given for this social gap (Bell et al., 2005): (a) the democratic deficit; although opinion measurements are in favor of decisions for wind power development, these decisions may be cancelled or postponed by minorities who oppose wind power. In that case the outcome of the process does not reflect the opinion of the majority (Toke, 2002) (b) the "Qualified Support" explanation: many people who believe that wind power is a "good thing" also maintain that there are limits and controls that should be taken into account on a particular development (Wolsink, 2000). And (c) the "Shelf Interest" explanation; according to this explanation people support wind energy but they are against the wind turbines in their area. The actual meaning and content of NIMBY has been a subject of studies (Van der Horst, 2007; Wolsink, 2000). Measurements based 
on NIMBY effects depend on the stage of a wind farm project, although some empirical studies have not taken this factor into account (Ek, 2005; Warren et al., 2005). Poll opinion measurements have shown that the opposition is strongest at the planning stage but is definitely weaker when the facility becomes operational (Wolsink, 1994). A key role in influencing public attitudes is public participation. The right of groups of interest to participate in decisions and policies establishes a mutual relationship between wind power planners and the administrative authorities on one side and the public / stakeholders on the other side. The role of the public in receiving favorable decisions for wind power developments has been understood over the last twenty years; in the Rio Conference in 1992 the need for public participation was emphasized "one of the fundamental prerequisites for the achievement of sustainable development is broad participation in decision making. Furthermore, in the more specific context of environment and development, the need for new forms of participation has emerged. This includes the need for individuals, groups and organizations to participate in environmental impact assessment procedures and to know about and participate in decisions, particularly those which potentially affect the communities in which they live and work" (Chapter 23.2). It is well established by now that economic strategies, without taking into account environmental concerns, have failed to a large extent to achieve social justice (Ksentini, 1994). Orum and Heminway (2005) emphasize public participation as "participation includes traditional and innovative means of engaging communities and workers decisions about environmental health hazards and solutions". Even simply informing the public or the stakeholder groups about wind power projects and possible impacts is a form of participation. Consulting the public and stakeholder groups also links the public with the administrative estate and contributes to the acceptance of the plans. As different groups of interest are involved that is the authorities, investors, scientists, public and stakeholders, a Participatory Integrated Assessment (PIA) as a holistic procedure, seems to be a powerful tool for planning management at a local level (Ridder and Pahl-Wostl, 2005). Integrated assessment is defined by the European Environment Agency a tool "to provide relevant information to policy makers on a specific decision problem". Rotmans (1999) expressed a more functional view of Integrated Assessment as the author envisages it as an "an interdisciplinary process of combining, interpreting and communicating knowledge pieces of diverse scientific disciplines in such a way that insights are made available to decision makers". The main objective in a PIA approach is to use practical information, scientific assessment and policy making practices to adopt measures and activities at a local level and finally to achieve public acceptance. Local level planning includes a wide range of activities such as tourism, walking, mountaineering, camping and all these activities should be accommodated without conflicts and impact between each other. The need for an Integrated Approach has already been recognized in many different fields referring to environmental protection and management Kitsiou and Karydis, 2011; Karydis and Kitsiou, in press). This way an environmental problem or an activity like wind power production can be placed in its global dimension and in connection with other environmental problems. Understanding environmental and ecosystem processes, taking into account social and anthropogenic pressures, positive aspects from the use of renewable energy sources and their environmental impact, a better overall assessment can be achieved leading to more rational and documented decision making. Arguments used by groups of people opposed to wind power developments in their area are given in Table 1. The main argument is the impact on landscape aesthetics. Noise is the second argument of the list. Shadow flicker, dangers from ice throw and structure failure are low in priority whenever opinion measurements are carried out. In addition to environmental reasons, opposed groups also make use of arguments referring to poor benefits of their local economy. The impact on tourism and limited job creation are popular answers. Technical arguments such as intermittent power supply, potential health effects from electromagnetic fields and problems with television reception (ghosting and jittering of television image) are often reported.

In addition to any information from public participation, an integrated approach should also include: (a) information about the natural environment of the site (b) qualitative and quantitative description of the existing anthropogenic pressures in the area (c) social attitudes (d) economic aspects (e) possible benefits of the area. This information should be analyzed and lead to an acceptable planning cycle based on the following stages: (a) planning (b) policy making (c) implementation (d) impact evaluation and (e) possible readjustment of steps (b) and (c). However, public attitudes towards wind energy are not always negative. Wind Energy in Denmark seems to enjoy high public acceptance (Krohn and Damborg, 1999, Landenburg, 2008). One of the main reasons for the high acceptance at both national and local scale was ownership. Danish legislation has favored the 
formation of local wind energy cooperatives characterized by limited ownership of shares in wind farms (Moller, 2010). This way a wide spread of ownership was established, providing income at a local level. It seems that a combination of public participation and economic benefits increase the possibility of accepting wind farm installations at a local level (McLaren Loring, 2007; Wolsink, 2007; Toke, 2005).

\section{LANDSCAPE: AESTHETIC AND SCEPTICISM}

The conflict already mentioned in the previous section between a positive attitude of the public to wind power projects and the skepticism at a local level, it is also reflected in selecting the site. The view that wind energy facilities deploring at a large scale are going to alter the landscape has gained ground (Pasqualetti, 2000; Ek, 2005). This conflict rises from a false supposition concerning public acceptance; but as energy policies are placed at either national or European level, these national and supra-national regulations cannot be accommodated at a local level which in turn act as "barriers" during the implementation stage (EC, 2007). Planners and investors used to take the support of NGO's, public and stakeholders for granted as far as wind energy production is concerned relying on the "clean" and "green" perceptions (Warren et al., 2005). The consequence of these assumptions followed by wind farm permits issued with top down procedures alienated the public and stakeholders undermining the participatory procedure.

The concept of a landscape as conceived by the objecting public is a complex meaning; it refers to ecological entities including geological formations, flora and fauna as well as the human presence expressed through a number of ways: housing, land development and users such as farmers, tour operators and tourists (Woods, 2003). This means that a formal Environmental Impact Assessment (EIA) can hardly describe all negative effects referring to landscape values (Morris and Therivel, 2009). The way a layman understands the term "nature" is often connected with the meaning of the term "rurality". There are two major conceptions deriving from rurality that influence public attitudes: the "holistic conception" that is nature is "taken to include everything existing" and the "separatist conception" in which processes take place without human presence (Woods, 2003). Local sites suitable for wind power developments form distinctive habitats for flora and fauna. The combination of abiotic-biotic elements produces a unique profile referring to biological values such as species richness, biodiversity and conservation. In addition, a local landscape is part of a wider ecosystem and it is therefore obvious that any local impacts also affect the whole ecosystem. Another argument often supported by environmentalists is the ecosystem fragility; isolated ecosystemic units are particularly sensitive and vulnerable even on the slightest human pressure. All these reservations concerning landscape impacts have been condensed in the slogan "think globally, act locally". But more than any ecological impact the public is opposed to wind farms for aesthetic reasons. In Denmark high pressure for higher visibility on landscapes was a reason why wind power projects failed; the EIA became mandatory since 90s for groups of three turbines and more (Moller, 2010). Two factors have been identified as the main keys for wind farm installations (a) the distance from the site: as a rule people living near the wind farm are opposed more actively than people living further away and (b) People matter: the social, economic and demographic profile of people near the wind farm plays a major role about their attitudes towards the development (Van der Horst and Toke, 2010).

All these problems mentioned above turned investors to marine wind parks (Wolsink, 2010). There are definite advantages in marine wind parks: (a) the wind regime in the marine environment is smoother and stronger (b) they are far from residential areas (c) the noise does not disturb human activities (d) offshore wind turbines do not cause aesthetic problems when they are out of view from the coast. However, expectations that there would be less "public resistance" were proved rather naïve and optimistic (Jay, 2008). Implementation of wind power projects causes conflicts with different groups of stakeholders such as fishermen and professionals involved in recreational activities. In addition, the turbine and installation costs are much higher: "marinization" of wind turbines to resist corrosion and foundation of the tower in the sea bottom is an expensive technology; grid connection and maintenance costs are also high. As the sea wind farm technology is twenty five years behind the land wind generator technology, many problems are waiting to be solved. In the initial step, the marine wind turbines were semi-offshore: the wind farms at Zeebrugge in Belgium and Blyth in Northumberland were both built on harbor piers (Still, 2001; Wolsink, 2010). Large, real offshore wind farms were built in Middelgrunden in the Baltic Sea (40MW) and Horns Rev in the North Sea (160MW) during 2001 and 2002 respectively by Denmark (Wolsink, 2010). The 
"seascape" problem remains as long as the wind turbines can be seen from the shore (Danielson, 1995). Discussions on the acceptability of marine wind farms have shown that "seascape impacts" are among the most important issues to be considered by the policy makers (Firestone et al., 2009; Landerburg, 2008). The attitudes of people living in the nearby areas reflect "mixed feelings". Opinion measurements among the stakeholder in Germany showed that only $50 \%$ of the people asked were in favor of wind energy technology whereas for land based wind farms the percentage in favor was as high as 83\% (Gee, 2010). German people involved in specific land and seascape services seem to oppose very strongly wind farm developments. Visitors to coastal holiday resorts, tourism operators relying on the beauty of the seascape and people enjoying recreational activities are among the groups of interest opposed to offshore wind farms. On the other hand it was found in Denmark (Landenburg, 2008) that there was a high percentage of willingness by people to accept more offshore wind farms. It is interesting that a higher percentage of older people considered that offshore marine wind farms were intrusive in the marine environment (Bishop and Miller, 2007). It was also noticed that public involvement at an earlier stage of the planning processes enhances the overall acceptance. The early involvement of the public has been supported by many authors (Keller, 2009; Karydis and Kitsiou, 2012). The attitudes of people examined in opinion polls were rather interesting (Gee, 2010). Some of them were in favor of offshore wind power development to "rescue" the land from similar activities; comments like "I hope for less wind turbines on land. There are too many turbine sticks on land already" are common (in Gee, 2010). People opposed to marine wind farms had different arguments: despoiling of the sea ("our coast is covered in wind mills- let's avoid the same fate for the sea"), loss of open horizon ("an open landscape and expansive horizon represent the most important capital of this landscape. This is being destroyed for absolutely no gain") or industrialization of the sea ("destruction of our horizon, financial gain for only a handful of people"). The struggle between offshore development of wind farms and the seascape protection is an ongoing issue. More work on attitudes and skepticism of people should be carried out for a better understanding so as to improve the degree of acceptance for offshore wind parks under environmentally acceptable specifications and conditions. As there are vast marine areas suitable for wind turbine installation, the marine environment can be the definite solution for wind power energy generation.

\section{WIND TURBINES: HUMAN HEALTH PROBLEMS}

\section{Noise pollution}

It is well established that humans exposed to high noise levels are suffering from hearing loss. Measures to mitigate noise impact were known since ancient times. Metalwork involving hammers were banned in Ancient Athens within the city limits. In Ancient Rome, measures had been taken concerning wagons with iron wheels that were disrupting the sleep whereas in some cities of Medieval Europe, horse carriages were not allowed during the night (WHO, 1999).

Noise is the usual complaint made by people opposed to wind turbines if their homes are nearby the wind farm. If the distance of a residential area from the wind farm is about one kilometer, then there is a problem. Two sources of turbine noise have been identified so far: (a) aerodynamic noise: it is the noise from the wind blades having a broadband character. It is caused by the flow of air around the blades. This noise is the dominant noise problem for wind turbine designers as it is not easy to be reduced (Pedersen and Persson Waye, 2004) and (b) Mechanical noise: it is mainly due to the gearbox function; the dominant frequencies are below $1000 \mathrm{~Hz}$ and is characterized by discrete tone components. It has been found out that the tones are more annoying than the noise itself (Pederson and Persson Waye, 2004). The noise produced by a single turbine has a level varying between 90 and $100 \mathrm{~dB}(\mathrm{~A})$ at wind speed $8 \mathrm{~m} / \mathrm{sec}$; this results in a noise level of about 33-40 dB(A) at $500 \mathrm{~m}$ distance but this depends also on the topography as well as ground and meteorological conditions in the area (Pedersen and Persson Wayne, 2007). Although noise level from wind turbines seems to be relatively low compared to traffic and aircraft noises in urbanized areas, it can be unacceptable in a rural environment: the sound amplitude is synchronized by the roor blades producing a rhythmical intermittent sound. This type of noise seems to be more annoying mainly due to quantitative characteristics rather than the noise level measured in a $\mathrm{dB}(\mathrm{A})$ scale. In addition, noise intensifies psychological stress. The stress depends not only on the level and frequency of the sound but also on the duration, the intermittency and the period of the day or night. In that case the $\mathrm{dB}$ scale can hardly help to set specifications and limits. This issue has already been raised with Minnesota's 
Department of Health where the view that wind turbines need a separate noise standard was supported (Rosenquist, 2012).

It is known that quantification of the sound has been mainly based on the sound amplitude described in units of pressure per unit area, microPascals $(\mu \mathrm{Pa})$. The amplitude is often converted in picowatts $\left(10^{-12}\right.$ watts) or sound intensity $\left(10^{-12}\right.$ watts $\left.\mathrm{m}^{-2}\right)$. Sound intensity is felt by humans as the loudness of the sound (Therivel, 2009). It was therefore found more practical to adopt a logarithmic scale known as the decibel $(\mathrm{dB})$ scale instead. As Environmental Impact Assessment (EIA) studies are concerned with the loudness experienced by people rather than the actual physical magnitude of the sound, an A-weighted curve is applied to provide a single figure index that takes into account the sensitivity of the human ear. Hence loudness is expressed in $\mathrm{dB}(\mathrm{A})$ rather than simple $\mathrm{dB}$.

Humans can perceive sounds ranging in frequency between 20 and $20,000 \mathrm{~Hz}$. This perception is not uniform over the frequency spectrum but there is an acoustical window that shows the human ear is more sensitive between 500 and $8,000 \mathrm{~Hz}$. Hearing impairment occurs within this range. The A-weighted filter diminishes the contribution of sound values below $500 \mathrm{~Hz}$ and ignores acoustical energy below $20 \mathrm{~Hz}$ (Alver-Pereira and Castelo Branco, 2007a). This is why an issue that needs special attention regarding noise produced by wind turbines is potential biological effects caused by infrasounds $(0-20 \mathrm{~Hz})$ and low-frequency noise $(20-500 \mathrm{~Hz})$. This range of frequencies $(0-500 \mathrm{~Hz})$ known as ILFN has been lately a subject of medical research regarding pathological effects leading to vibro-acoustic disease.

It has been established by now that noise can cause to humans three kinds of biological impairment (a) hearing loss: this is the only type of impairment recognized medically and legally since a long time (b) "annoyance". According to the European Commission noise team (EC, 2000) "annoyance is a scientific expression for non-specific disturbance by noise. A large number of specific effects has been reported referring to reduced enjoyment with sleep, communication problems, reading, listening to music etc as well as mental health effects such as noise induced hearing problems, hypertension and ischemic heart disease" and (c) Vibro-Acoustic-Disease (VAD). VAD is a systemic disease caused by continuous exposure to ILFN (Castelo Branco and Alves-Pereira, 2004; AlverPereira and Castelo Branco, 2007a). The symptoms are known as the "Wind Turbine Syndrome". Research carried out by Castelo Branco and Alves-Pereira (2007b) has come to the conclusion that their "results irrefutably demonstrate that wind turbines in the proximity of residential areas produce acoustical environments that can lead to the development of VAD in nearby home-dwellers". This syndrome is characterized by sleep disturbance, headaches, dizziness, nausea, rapid heart rate and panic attacks.

A cross sectional study on wind turbine noise was carried out in seven areas in Sweden (Pedersen and Persson Waye, 2007). The objective of the study was to evaluate the relevance of perception and annoyance of people living near wind parks, caused by wind turbine noise. The study ended in a number of interesting conclusions: (a) the risk of being annoyed by wind turbines is proportional to A-weighted sound pressure levels (b) the degree of annoyance is higher in rural areas as compared to urbanized areas (c) the geographical characteristics should be taken into account as they play an important role in the final outcome of annoyance and (d) the dose-response relations should be assessed for each type of environment and not at a general level.

\section{Shadow flicker}

Shadow flicker is a rather unusual impact on human health; it can be effective only if wind farms are in the vicinity of residential areas. Shadow flicker is an intermittent shadow of the blades over the neighboring houses when the sun passes behind the hub of a wind turbine (Etherington, 2010). It has been reported that people suffering from photosensitive epilepsy are at risk. However, this risk is considered as relatively low as the rate of rotation is usually below critical values. According to the Department of Business, Enterprise and Regulatory Reform (DBERR, 2010) there is no impact if the distance between turbine blades and houses exceeds the length of the diameter blades by ten times. This means that as for most of the turbines this distance is between 800 and $1000 \mathrm{~m}$ (Smedley, 2010). However, there is a controversy about the distance: Harding et al. (2008) reported that the proportion of patients showing effects form flicker did not decrease significantly until the distance was greater than 100 times the hub height.

The pulsating light can make indoor activities of people living nearby uncomfortable. It can make watching TV difficult and cause general disturbance as well as psychological distress. The 
phenomenon is particularly intense in high altitudes where the sun path is rather low. Predicting shadow flicker is a rather complex procedure as many factors are involved (Brinckerhoff, 2011; Smedly et al., 2010): (a) building location relative to the path of the sun and the turbines (b) distance of turbines from buildings (c) size of house windows facing the turbines (d) turbine height and rotor diameter (e) local topography and vegetation; building intervening between turbines and houses (f) time of the year and $(\mathrm{g})$ rotor orientation induced by wind direction. Shadow flicker effect is reduced if the distance is longer than $1000 \mathrm{~m}$, low visibility conditions prevail, the room that the shadow casts is lighted or the shadow is screened by trees. Efforts have been made to model shadow flicker as part of the design and evaluation of wind power projects (WIND Engineers, Inc., 2003).

Health problems can also be caused by reflecting flashing if the sun is behind or sidewise of the observer. Turbine blades should not be reflective (Harding et al., 2008).

\section{EFFECTS ON THE TERRESTRIAL ECOSYSTEMS}

Wind power farms take up big areas usually on the top of hills or mountains. Construction of roadways to get access to turbines, bulldozing of hill sides to create flat areas for the foundations as well as massive amounts of concrete for the bases of the of the turbine towers. This practice changes the geomorphology of the area, devastates a great deal of the vegetation and destroys many nesting sites.

The impact on wildlife is particularly serious on birds and bats, victims of rotor blades. Even when the rotor's blades move slowly, the speed at their tips can be as high as $200 \mathrm{~km} / \mathrm{h}$. There are records of bird deaths by turbine blades in Germany (BSEO, 2008), Sweden (Ornithological Society at Gotland, 2008) and Norway (Norwegian Ornithological Society, 2005) as well as Everaert and Stienen (2007). Red kites, Burrards, white tailed sea eagles and golden eagles were among the 47,000 dead birds recorded on an average per year. It has also been found that migratory birds are more vulnerable to accident with wind mill blades (Langston \& Pullan, 2003; Drewitt and Langston, 2006). This is because birds that are already on flyways cannot avoid adverse weather conditions. In addition they will be more susceptible if they descend lower down to land due to low clouding (Drewitt and Langston, 2006). It has been reported that in the Altamont Pass in Northern California, it was decided during 2005 to close half of the 5,000 windmills to protect migratory birds (Etherington, 2010). The ecological effects from wind turbines (both terrestrial and offshore) are summarized in Table 2. There are papers rich in information on bird deaths. Measurements on bird fatalities are carried out in wind farm facilities as well although these results have been disputed. Similar problems are encountered with bats.

Table 2. Ecological impacts from wind farm developments

\begin{tabular}{|c|c|c|}
\hline Impact & Impact description & Reference \\
\hline Birds & Bird collisions with turbine blades & $\begin{array}{l}\text { Kunz et al. (2007a) } \\
\text { Edkins (2008) } \\
\text { Everaert \& Stienen (2007) } \\
\text { Kuvlesky et al. (2007) } \\
\text { NWCC (1999) }\end{array}$ \\
\hline Bats & $\begin{array}{l}\text { Bird collisions with turbine blades } \\
\text { Lung explosion due to pressure } \\
\text { fluctuations }\end{array}$ & $\begin{array}{l}\text { William (2004) } \\
\text { Edkins (2008) } \\
\text { Kunz et al. (2007b) }\end{array}$ \\
\hline Cerateans & $\begin{array}{l}\text { Hearing loss } \\
\text { Behavioral problems }\end{array}$ & $\begin{array}{l}\text { Parsons et al. (2008) } \\
\text { Nowacek et al. (2007) } \\
\text { Carstensen et al. (2006) } \\
\text { Bailey et al. (2010) } \\
\text { Koschinski et al. (2003) }\end{array}$ \\
\hline Seabirds & Accidents with turbine blades & Garthe \& Huppop (2004) \\
\hline Demersal fishes & Decreased richness and diversity & Wilhelmsson et al. (2006) \\
\hline
\end{tabular}

It has been estimated that bird strikes on wind turbine blades range from 0 collisions/ turbine/ year up to $>30$ collisions/ turbine/ year (Kuvlesky et al., 2007); other researchers estimate bird fatality 
rates due to wind turbine blade collisions as high as 60 dead birds/ turbine/ year (Edkins, 2008). This variability is due to many factors. Although bird collisions on wind turbine blades were observed since the 70s and research in this field has been going on over the last twenty years, the number of publications in peer review journals is very limited (Kuvlesky et al., 2007). Most of this type of information exists in the form of articles in the daily press and magazines, assessment prepared for wind energy stakeholders, unpublished reports and other forms of gray literature. The initial estimates on wind turbine bird mortality were rather optimistic; in the US the annual anthropogenic avian mortality was predicted less than $0.01 \%$ of bird population, a number that soon had to be revised as some wind farm areas acted as areas where bird population sinks (Edkins, 2008). More realistic estimates showed that the numbers of birds killed annually would vary from 300-400 to $3000-5700$ by 2020 whereas bird mortalities from wind blades could be as high as 300,000 birds per year nationwide by 2030 (Edkins, 2008). This number is equal to 0-20 birds per MW per year. A review on recorded collision rates has been given by Drewitt and Langston (2006). However, there is not enough information whether nocturnally migrating waterfowl is able to detect and avoid turbines.

Everaert and Stienen (2006) calculated death fatalities by wind turbines at the eastern port breakwater in Zeebrugge, Belgium, during the breeding seasons in 2004 and 2005. It was estimated that the mean number of lethal collisions including the Common Tern Sterna hirundo, the Sandwitch Tern Sterna sandvicensis and the Little Tern Sterna albifrons was 6.7 deaths/ turbine/ year during 2004 and 2005 but bird death percentage was almost twice as high in the turbine area facing the breakwater. The total number of fatalities during the two year period including other species (such as seagulls) was approximately 20 dead birds/ turbine/ year but fatalities caused by turbines on the sea directed breakwater were more than $30 \%$. It was also estimated by the same authors that collision possibility for Common Terns crossing the line of wind turbines was about $0.110-0.118 \%$ for flight at rotor height but much lower for all flights $(0.007-0.030 \%)$.

The problem of bird deaths seem to be more serious with nocturnally active birds to wind energy developments. Scientific information is needed to elucidate the different aspects of the problem (Kunz et al., 2007a): (a) assessment of impact (residential and migratory birds) (b) quantification of fatality rates (c) understanding the cause of bird fatality and (d) development and implementation of methods for bird fatality reduction. Measures to mitigate the problem (Edkins, 2008) may include feathering of turbines during high-risk periods, making the blades more visible, reducing lighting, reducing the attractiveness of the areas around the turbines and/ or bird deterrents.

The bird mortality problem needs monitoring and understanding before mitigation measures will be implemented. In the author's opinion the significance of the problem has not been given enough attention as it is addressed simply as "one of the impacts" in environmental impact assessment studies. Everart and Stienen (2007) seem to be cautious about bird fatalities when wind farm developments are designed: "...we recommend that there should be precautionary avoidance of constructing new wind turbines close to any important breeding colony of terns or gulls, nor should artificial breeding sites be constructed near wind turbines, especially not within the frequent foraging flight paths. An exhaustive study before the selection of future wind farm locations is a key factor to avoid deleterious impacts of wind farms on birds. In general, current knowledge indicates that there should be precautionary avoidance of locating wind farms in all important bird areas and / or migration routes".

Bats seem to be another victim of wind mill blades. As bats navigate using an echo sounding device they fail to locate the position of the moving blades. If we take into account the fact that bats forage near operating turbines, the problem becomes more serious. Bat fatalities gained attention after 2003. It has been estimated that $1400-4000$ bats were killed at the Mountaineer Wind Energy Center in West Virginia. Death rates equal to about 30 bats per MW per Year (Edkins, 2008). Parallel studies in European Countries and the USA seem to estimate bat death rates to the number of 1520 bats per turbine per year for the EU whereas bat death rates seem to be higher for the US (1-40 bats/MW/year). The peak in bat fatality is usually observed during late summer and early autumn. There are many explanations regarding exploratory activities, roost attraction and prey availability. In addition to collisions to rotor blades, it is now known that bat fatality is mainly caused by barotraumas, due to fluctuations of atmospheric pressure caused by the rotating turbine blades; these fluctuations cause rapid decompression finally leading to lung bursting (Edkins, 2008; Kunz et al., 2007b). 
Wind farms founded on peaty soil seem to cause an impact on the peat and therefore peat-land habitats may be threatened: excavation for access roads create a new surface drainage network and the import of materials can change the water chemistry causing geo-bio-chemical changes. Although no work on peaty wind farm sites has been published, it has been reported for cultivating land that drainage of peaty soils causes compaction of peat, decrease of its water retaining capacity and finally peat exhaustion (Baranovskii, 1999).

\section{EFFECTS ON THE MARINE ECOSYSTEM}

The main effects in the marine ecosystem derive from noise and vibrations (Koschinski et al., 2003). Many marine organisms like crustaceans and fish can detect sounds whereas marine mammals also produce characteristic sounds. (Popper et al., 2004; Henninger and Watson, 2005). The impact from anthropogenic noise on marine organisms depends on a number of factors (a) how well the noise propagates (b) frequency characteristics and (c) duration. Although sound propagation in deep waters is well understood, it is a rather complicated phenomenon in shallow coastal waters $(<200 \mathrm{~m})$. The information referring to background noise levels in coastal waters are rather limited (Bailey et al., 2010). However, most of human activities take place in the coastal water zone and therefore it is difficult to assess the noise impact on wildlife populations. Coastal waters are the habitat for many marine mammals. The harbor porpoise Phocoena phocoena that uses the coastal system for calving and nursing (Koschinski, 2002) is an example. There are two kinds of noises: (a) noise during the construction stage. It is the noise produced during pile-driving; monopoles are driven into the seabed by the use of large pile hammers. Noise from ramming and other construction such as seismic exploration, increased sea traffic, trenching and dredging noises may have an effect on marine organisms and (b) the operational noise due to the blades and gearbox. Measurements on piledriving showed that the sound levels reached $205 \mathrm{~dB}$ and this noise was detectable at a distance of $70 \mathrm{~km}$ (Bailey et al., 2010). It has been reported by the same authors that bottlenose dolphins and minke whales may suffer from behavioral problems up to $50 \mathrm{~km}$ away. However, the actual zone of disturbance seems to be much shorter. Relevant experience in the Baltic Sea has shown that the zone characterized by reduced number of "clicks" of harbor porpoises was limited to $16 \mathrm{~km}$ away from wind farms that cover nowadays areas ranging between 20 and $30 \mathrm{~km}^{2}$ (Carstensen et al., 2006). It is known that pods (groups of whales) use specific sounds for recognition of the members of the pod (Levington, 2001). A "click" type of signal is also used for echo-location; this way an animal can estimate the distance from surfaces reflecting the clicks. The sensitivity of cetaceans to man-made sounds is already known from naval maneuvers using sonar devices. Underwater sounds can lead cetaceans way out of their route and eventually they can be stranded on the beaches (Frantzis, 1998; 2004). As marine wind turbine installations and their impact on marine organisms is a relatively new field in environmental impact assessment studies, more research should be carried out aiming at: (a) to determine the background noise (b) to define the effect zone for sea mammals and (c) in biological surveys and monitoring studies carried out in the wider area, the possible impact of noise on the various forms of marine life should be taken into account. The impact in the marine environment due to wind turbines is summarized in Table 2. In addition to seabird mortalities, the problem with underwater noise seems to be serious for sea mammals (cetaceans) and possibly for fish as well. As offshore wind turbine technology is relatively new and the cost of marine research is particularly high there is not enough information so far that would allow scientists and policy makers to define thresholds for noise annoyance or safe distancing between wind facilities and cetacean habitats.

Behavioral reactions of porpoises and harbor seals have been studied in Fortune Channel, Vancouver Island, British Columbia, Canada (Koschinski et al., 2003). Operational noise emitted at 8 $\mathrm{ms}^{-1}$ by a $550 \mathrm{~kW}$ Wind World wind turbine based on monopole was recorded. The original recording was modified to simulate a $2 \mathrm{MW}$ offshore wind-turbine. The observation on harbor porpoises showed that (a) the animals were able to hear the wind-turbine sounds from a CD player. There is limited information on hearing abilities of harbor porpoises. However, it is known that low frequencies, below $100 \mathrm{~Hz}$ are the most important for harbor porpoise communication; they have responded to signals ranging from $500 \mathrm{~Hz}$ down to 80 and $100 \mathrm{~Hz}(\mathrm{~b})$ the animals are cautious when they receive the acoustic stimulus. Noise increased surfacing rate making them avoid staying near the source of sound and (c) porpoise explored the sound source using their biosonar. Similar behavioral pattern has been shown by harbor seals. Harbor seals possess better low frequency hearing and reacted to the noise by increasing their distance from the sound; they were also trying to 
avoid the sound by lifting their head out of the water. A possible indirect effect regarding their prey fish which may avoid the sound source has also been reported. Another possible effect is noise masking: as harbor seals produce calls at low frequencies (Richardson et al., 1995), these may be masked by anthropogenic noise of the same frequency. Response weakening (desensitization) was also difficult to be explained as it could either be the result of habituation or hearing impairment. Irrespective of research progress in sea mammal acoustic impacts, mitigation measures should be taken during offshore wind turbine construction: (a) to avoid work during calving and reproduction (b) to allow sufficient low noise habitat for sheltering and (c) to reduce sound emissions using bubble curtains (Wursig et al., 2000). Underwater bubbles can attenuate sound propagation through water masses due to density mismatch and concomitant reflection as well as absorption of sound waves. No published work still exists on impact of pile-driving on whales. However, the effects of air guns on the bowhead Balaena mysticetus in Arctic waters has been reported (Madsen et al., 2006; Richardson et al., 1999). It was found that whales were avoiding air guns at a distance of about 20 $\mathrm{km}$ and concluded that pile-driving can affect whales over large ranges depending on the conditions of sound propagation. The effects of noise from the operation of offshore turbines on baleen whales have not been studied either.

There is not enough information regarding the ability of fish to hear and respond to sounds. According to the existing information (Popper et al., 2004) fish differ in their ability to detect and respond to ultrasonic sounds. Fish are classified according to Popper et al. (2003) "as hearing specialists or non-hearing specialists (or generalists)". The hearing of non-specialists can detect sounds of $250-1500 \mathrm{~Hz}$ whereas hearing specialist fish can detect sounds $3000 \mathrm{~Hz}$ or above. It has also been shown that some clupeid fish such as blueback herring can respond to ultrasonic sounds up to $180 \mathrm{kHz}$ (Mann et al., 2001). It is interesting that both categories of fish can respond to low frequency sounds $250-1500 \mathrm{~Hz}$ which is the sound frequency range of wind turbines. It is not known as yet the influence of offshore wind power turbines on clupeid fish. However, the effects of offshore wind turbines on fish are not limited to sound effects but also affect fish habitats of demersal fish. Fish often utilize man made underwater structures place on the bottom of the sea either intentionally (piers, monopoles, lighthouse foundation structures) or unintentionally (shipwrecks) as habitats. Humans sometimes encourage this practice (artificial reefs) to increase fishery activities, to mitigate environmental impacts or to increase the recreational value of an area such as diving (Ambrose, 1994). These artificial reefs can also support a rich epibiota of many marine plants and invertebrates. Although they can hold greater fish densities, the flora and the fauna can be different from the marine community of the adjacent area. Studies carried out by Wilhelmsson et al. (2006) have shown that biological communities settled on monopiles, would not have been there otherwise. It was further found that fish abundance was greater near the turbines. On the contrary species richness and diversity $\left(\mathrm{H}^{\prime}\right)$ were lower compared to the surrounding seabed. The authors (Wilhelmsson et al., 2006) maintain that monopoles can act as artificial reefs and fish aggregation habitats for demersal fish which is a rather positive effect for the marine environment.

\section{DISCUSSION}

When wind mill power appeared in the 70 s as a form of renewable energy on a commercial scale, it looked as the ideal alternative to fossil fuel power industry. It was then recognized that the only problem was the high cost of production compared to traditional coal, crude oil or gas power stations, turbine designers had focused on making the turbines more competitive as far as the electricity production cost is concerned. Impact wise wind turbines were considered as an absolutely clean form of energy with zero carbon dioxide emissions as well as zero atmospheric pollution from carbon monoxide, sulfur dioxide and nitrogen oxides. Public acceptance at that time was very high. Slowly, environmental problems were identified: landscape problems concerning aesthetics and functionality and noise were the usual arguments opposed to wind farm developments. Ecosystem effects were added and attitudes of people changed. The dominant attitude is "yes to wind energy but not near our house". Nowadays it does not matter where a wind power farm is going to be installed, as there is always strong opposition by small but influential and aggressive minorities.

All negative views opposing to wind power development stem from the same core: public attitudes towards wind power. Public attitudes regarding wind farm environmental impact are subjective to some extent as they depend on person's knowledge on wind power technology (Eltham et al., 2008). People objecting are usually influenced by mass media and reports, opinions of friends and opinions of people living nearby a wind farm (Devine-Wright, 2005). Two profiles are shaping in opinion 
measurements about wind energy (Krohn and Damborg, 1999): (a) the profile of the 'nay-sayer' and (b) the profile of the 'yes-sayer'. The debate is inexhaustible as each site sticks to its own arguments; nay-sayers: (1) it is not possible for wind power to solve the power demand problem (2) the function of wind turbines depends on the wind hence it is an unreliable source of energy (3) high production cost (4) wind turbines intrude into pristine landscapes and (5) they are noisy. The other side, the yes-sayers maintain that: (1) wind energy is a renewable energy source (2) the theory of climate change should be taken into account (3) wind is an unlimited energy resource (4) wind technology is not polluting the atmosphere and (5) wind power is a safe source of energy.

It is an important point for policy makers and stakeholders to be able to understand 'what the public thinks' (Walker, 1995). Before that however, what we mean by public has to be refined. Considering as 'the public' an amorphous mass is a wrong approach. Public opinion is closely connected to specific groups in the society: some of them represent views at a national level, thinking in favor of wind energy on a principle basis as a renewable form of energy in an abstract and remote way, whereas local public opinion is based on person's experience by specific wind farm developments. Another classification system for the public is 'active' and 'passive' publics (Walker, 1995). An active public organizes pressure groups and uses mass media while people classified as passive public respond only if their views are pursued. On the other hand the meaning of public acceptance does not refer either to generalist's or 'localist's opinions but encompasses market acceptance, local community acceptance as well as acceptance by key stakeholders and policy makers (Firestone et al., 2009). In UK a number of factors influencing the nay-sayers arguments have been identified: (a) investors often select sites of high landscape value (b) the exponential development of wind farms was not supported by public consultation and involvement (c) lack of national co-ordinated policy is causing conflicts and (d) floor is given to high profile personalities opposed to wind energy is given by mass media. As it happens the louder the voices in the mass media, the better the political responses; it is obvious that the 'general' public can easily adopt negative views about wind mill energy (Walker, 1995).

It is also interesting that attitudes differ before and after a wind power development. In an early study performed in the Netherlands (Wolsink, 1989) it was found that acceptance increased when the projects were materialized. Residents in Delabole, Cornwall (UK) were asked in 1990 to express their opinion about the wind power project. It was found out that when they were asked again two years later (1992), the percentage of acceptance had increased after having lived with the turbines for six months (Eltham et al., 2008. A similar type of 'before' and 'after' survey performed in Wales showed that the percentage of initial support was $1 \%$, whereas after the construction this percentage jumped up to $66 \%$ (Eltham et al., 2008). This delayed acceptance showed that a better consultation and communication with local populations is required; "the decision-announce-defend approach to siting with minimal public involvement has been shown to repeatedly antagonize and create public mistrust, concern and ultimately conflict" (Walker, 1995).

Exposed hill tops or upland landscapes seem to be ideal places for the exploration of wind energy. Unfortunately these areas are considered as a pristine environment and therefore any installation of wind turbines is characterized as "industrialization of a landscape" (Firestone et al., 2009). Similar views have been reported by the same authors from opinion measurements in Germany where the most common reason for rejection of wind power projects is the "reduction in the values of the existing landscapes". The concept of landscape impact is extended to the marine environment: according to Kempton et al. (2005) the feelings of coastal residents can be condensed in the sentence "there appears to be something special about the ocean, a feeling which for many people underpins their opposition to the project".

The visual impact is the most negative feature in wind farm facilities that citizens are concerned. Noise and disturbance to wildlife seem to have less importance. The variables identified as important in shaping negative public opinion are the location (terrestrial or marine) and the characteristics of turbines such as size, color, orientation and layout (Walker, 1995). Protection groups in some cases can play an important role: Eltham et al. (2008) reported that the Council for the Protection of Rural England (CPRE) can have substantial influence on planning decisions (Toke, 2005); it was found in England and Wales that every application objected by CPRE had been refused planning permission. The planning system was therefore confronted with public resistance to wind farms. The offshore wind plan developments seemed to give an expectation that less public resistance will be encountered compared to land wind turbines: 'one solution of avoiding land use disputes and to 
reduce the noise and visual pollution, is to move the developments offshore' (Henderson, 2002). However, the expectations were very optimistic. Experience from different countries showed that the opposition against sea wind farms was as strong as the opposition for the terrestrial environment (Ellis et al. 2007; Firestone and Kempton, 2007). Opinion measurements on five offshore wind farms in the UK provided interesting results (Jay, 2008). People answered for all the five sites that land/seascape and construction noise was the main problem. For the three out of the five proposed sites cumulative effects of wind farms seemed to be of concern to people whereas impact on tourism, leisure activities, archaeology, fisheries and navigation were also among people's concerns. Problems in television reception were also reported for one site. More work is needed to understand people's objections and reservations about offshore harnessing of wind energy as well as the understanding of coastal and offshore environments in connection with the implications of development (Jay, 2008).

Among the various negative factors characterizing wind farm development such as noise, light, shadow flicker, effects on birds and general impact on the natural environment, the visual landscape factor dominates. The landscape values are more prominent in explaining attitudes compared to general positive views toward wind power. Every landscape image is not only characterized by spatial and structural features but also by landscape's spatial character in an area (Krause, 2001). The word 'landscape' incorporates a number of characteristics referring to natural and cultural space as well as to the variety and beauty of long-term natural and cultivated values. These should be the standards for evaluating the aesthetic quality of a particular site. Local peculiarities and traditions should also be taken into account. The final objective should be sustainability and landscape protection. Assessments of public opinion regarding the degree that wind turbines would spoil the Wadden Sea in the Netherlands showed that landscape was the strongest reason of opposition (Wolsink, 2007). The dominant characteristics for wind power accessibility or rejection were analyzed using Principal Component Analysis (PCA). Assessing the applicability of wind turbines in terms of visual intrusion, landscape quality and impact for a chosen location showed that most people thought that there were still several sites in the Wadden Sea available for wind farm installation. The greenhouse effect was considered as an insignificant explanation for supporting wind power planning in the area. The author further examined the acceptability in terms of the number of turbines, the height of the machines and the preference for smaller units; it was found that none of these factors could explain the variance referring to the acceptability of wind power projects in the Wadden Sea. On the contrary, people seemed to prefer small clusters of turbines rather than scattered solitary turbines. This is why a prior assessment of probable visual impacts has been recognized widely as a primary step of the planning process (Bishop and Miller, 2007). In spite of the research that has been carried out on wind farm acceptability there is still a lot of misunderstanding referring to people's attitudes. It has been reported (Wolsink, 2007) that 'ad-hoc questionnaires that are not based on clear conceptual frameworks and one-shot case studies on one wind development location often result in eclectic conclusions and very limited possibilities for identifying general trends'. In addition the view of policy makers that knowledge by the public on wind energy issues will improve the degree of acceptability is rather optimistic. Experience has shown that attitudes do not change (Wolsink, 2007).

Another issue related to wind farm sites that has not received so far adequate attention is known as 'environmental justice' (Van der Horst and Toke, 2010). It means that different groups of people are exposed unequally to environmental impacts. Experience has shown that noxious or locally unwanted facilities are usually sited in areas where population is vulnerable and deprived. This problem was very intense in the US where polluting facilities and waste dumps were sited in the vicinity of settlements inhabited by poor people or ethnic minorities. Although the situation is different in the UK, it was found that in many cases wind farm planning was closely associated with some proxy indicators of vulnerability and deprivation (Van der Horst and Toke, 2010). When wind farm impact is assessed another problem is surfacing: if the term 'impacts' is limited to scientifically measured variables that have proven to cause physical harm, then the issue of 'environmental equity' arises. But if in addition to 'proven impacts', perceived risks are added then environmental equity can become a decisive planning tool in wind farm developments. Building of wind farms, digging of trenches for laying the cables and building the concrete bases are among the perceived risks. In addition, if changes in a landscape are considered as environmental impact, then environmental equity can also influence wind farm planning. 
In spite of the contribution of wind farms to eliminate the impact from the anthropogenic ally driven global climate change (Huntley et al., 2006), the scale of exponential development of wind farms raises questions about effects on wildlife (Drewitt and Langston, 2006). A wind farm is not just an assemblage of wind turbines but also comprises interconnection cables, transformer station, meteorological antenna, access roads and visitor's center. This entire infrastructure is a potential risk for wildlife that has been recognized in several wind farms. Nowadays wind developments in the UK exclude from the coastline a minimum strip $8 \mathrm{~km}$ wide and can be as wide as $13 \mathrm{~km}$ in areas characterized by sensitive landscapes (Drewitt and Langston, 2006). In addition to the North-West England, wind farm developments have been excluded from depths less than $10 \mathrm{~m}$ deep or less to protect sea ducks that dive to feed from shallow habitats; this policy also leaves plenty of room for nearshore fishing and recreational activities.

The main effects on bird populations are (a) collision (b) displacement due to disturbance (c) barrier effects and (d) habitat loss (Drewitt and Langston, 2006). Direct mortality of birds results from direct collisions to turbine rotors, guy cables, power lines and meteorological masts. Collision risk depends on several factors including bird species, bird number, bird behavior, local topography, weather conditions as well as the use of lighting. The displacement of birds from the site can start as disturbance either during the construction or the operation phase and finally lead to habitat loss. Again site specific and species specific factors have to be delineated and a site to site EIA should be carried out. So far very few studies of displacement have been conclusive as BACl (Before and After Control Impact) studies are rare. Disturbance distance varies between 600 and $800 \mathrm{~m}$ although studies on bird breeding are far more inconclusive (Drewitt and Langston, 2006). Altering the flyways of migrating birds is also a form of displacement. The main effect is related to loss of energy due to deviation from the normal route. Habitat change and loss occurs at a small scale: the actual loss of habitat varies between $2-5 \%$ of the total development area (Fox et al. 2006) and depends on the size of installation. There is not much information on effects of offshore wind farms on birds but there is ongoing research in this field as well (Drewitt and Langston, 2006). Protection of bird population from wind farm effects requires suitable regulatory measures. In addition to national legislations, the Strategic Environmental Assessment (SEA) Directive 2001/42/EC, seems to be an effective tool (EC, 2001b). The SEA Directive integrates environmental issues into the projects at an early stage of planning. Special care is needed when developments are planned near Ramsar aquatic systems or areas protected by the Natura (EEC, 1992) or Biodiversity Directives (EEC, 1993). Investors should also avoid areas supporting high density or migratory bird populations, areas with high level of raptor activities and areas used for breeding. Mitigation measures have also been proposed (Drewitt and Lagston, 2006). These include best-practice measures that should be adopted as standard procedures during the construction and operation of the wind farms: avoidance of sensitive and protected habitats, implementation of post development monitoring, increased visibility of rotor blades and well timed construction schedules to avoid sensitive periods (i.e. reproduction) are among the principal measures to mitigate impacts. Parallel efforts are required to minimize the impact of wind turbines on bats (Kunz et al., 2007b). Future research should depict areas with high potential for impact on bats; long term monitoring coupled with hypothesis testing research (Karydis and Kitsiou, 2012) can answer a number of hypotheses set for understanding the problem. Finally access to wind energy facilities will contribute to a better collection of ecological information and therefore measures to mitigate bat fatalities can be formulated successfully.

Offshore wind farm development, in addition to effects on seabirds, they also cause the problem of 'acoustic pollution'. Acoustic pollution has special importance for cetaceans (whales, dolphins and porpoises) also known as 'vocal' taxonomic group as they are highly dependent on sounds for their social and behavioral responses (Weilgart, 2007). Anthropogenic ocean noise due to offshore wind farms is mainly the result of seismic surveys by geophysicists to study bottom geology (Gordon et al. 2003), noise from pile-driving and operational noise. These sources of noise can mask or obscure their natural sound and increase stress levels. Cetacean populations threatened by noise may abandon important habitats and reduce foraging efficiency or mating opportunities. Responses are species specific but also depend on age and behavioral states. There are already interesting reviews on marine mammals and noise (Richardson et al., 1995; Gordon et al., 2003; Weilgart, 2007) but research focused on the effects of turbine noise on cetaceans is limited. It is therefore premature to have a valid opinion on the effects of underwater noise from wind turbines and it is not therefore advisable to propose measures such as establishing safe exposure levels, reducing levels of noise and distancing noise from biological important areas. 
Underwater noise also affects fish populations causing permanent or temporary hearing loss, reduced catch rates and behavioral reactions to noise. However, information on sound detection and effects are mainly limited to clupeiform fishes (Mann et al., 2001).

\section{CONCLUSIONS}

There is already an experience from construction and operation of onshore wind farms that goes back to 70s as well as experience of at least one decade on offshore wind farms. The impact from terrestrial wind farm activities is known by now but any conclusions from marine wind parks should be considered as rather tentative. Irrespective of the type of wind farm, it is well established by now that opposition to wind farm developments is due to 'public attitudes'. It is not easy for public attitudes to 'be decoded' as they as depended on people's age, level of education, influence by friends or relatives and proximity of facilities to people's dwellings. The negative role of mass media should not be overlooked. The most popular objection used by opposed groups is 'landscape spoiling'. Noise and shadow flicker effects are the second and third arguments in the list of problems. Opinion measurements showed that impact on the natural environment is low in the agenda; the main effects at ecosystem levels are bird and bat deaths. This is a rather serious problem especially with raptor birds because their number is limited and they fly at a height which is more or less the height of the rotor blades.

Although experience on impacts in the marine environment is limited some tentative conclusions can also be drawn. Again the main argument of opposed groups is the spoiling of seascape aesthetics. Public attitudes are almost as much against offshore wind farm developments as in the onshore wind farms. The view expressed by policy makers that knowledge by the public will ease opposition has been proved in practice as rather optimistic and unrealistic. There are also problems with seabird fatalities.

Proximity to inhabited areas, national parks, areas protected under the Ramsar Convention, the Conservation Directive 'on natural habitats and of wildlife fauna and flora' (known as the Natura Directive) or the Directive referring to the protection of biodiversity should be avoided. Strategic environmental assessment studies should be carried out at an early stage of planning.

In the marine environment parallel activities should be taken into account when offshore wind farms are planned. These are: navigation, fishing, marine sports and other recreational activities; potential for seabed drilling for oil. A marine zone between the coastline and wind farms should be allowed to accommodate the coastal water activities mentioned above and protect the seascape view from the land. More research is needed for noise impact on both fish and sea mammals. Measures for the mitigation of underwater noise during the construction phase should also be implemented.

\section{REFERENCES}

Ackerman T. and Soder L. (2002), An overview of wind energy status 2002, Renewable and Sustainable Energy Reviews, 6, 67-128.

Alves-Perreira M. and Castello-Branco A.A. (2007a), Vibroacoustic disease: biological effects of infrasound and low-frequency noise explained by mechanotransduction cellular signaling, Progress in Biophysics and Molecular Biology, 93, 256-279.

Alves-Perreira M. and Castello-Branco A.A. (2007b), In home wind turbine noise is conductive to vibrioacoustic disease, Second International Meeting of Wind Turbine Noise, Lyon, France.

Ambrose R.F. (1994), Mitigating the effects of coastal power plant on a kelp forest communities; rational and requirements for an artificial reef, Bulletin of Marine Sciences, 55, 694-708.

Bailey H., Senior B., Simmon D., Rusin J., Picken G. and Thompson P.M. (2010), Assessing underwater noise levels during pile-driving at an offshore windfarm and its potential effects on marine mammals, Marine Pollution Bulletin, 60, 888-897.

Baranovskii A.Z. (1999), The formation of profile in drained peaty soils under agricultural use, Eurasian Soil Science, 32, 474-481.

BDERR (2010), Shadow flicker. At http://www.berr.gov.uk/energy/sources/renewable/planning/onshorewind/shadow-flicker/page18736.html.

Bell D., Gray T. and Hagget C. (2005), The "Social Gap" in wind farm siting decisions: explanations and policy responses, Environmental Politics, 14(4), 460-477.

Birnie P., Boyle A. and Redgwell C. (2009), International Law and the Environment, $3^{\text {rd }}$ Edition, Oxford University Press, Oxford. 
Bishop I.D. and Miller D.R. (2007), Visual assessment of off-shore wind turbines: the influence of distance, contrast, movement and social variables, Renewable Energy, 32, 814-831.

Brenner J.H.B. (1993), Impact of wind turbines on bird life, Proceedings of the European Community Wind Energy Conference, Lubeck-Travemunde, 8-12 March, pp. 20-23.

Brinckerhoff P. (2011), Update of UK Shadow Flicker Evidence Base, Department of Energy and Climate Change. Available at: www.decc.gov.uk .

Carstensen J., Heriksen O.D. and Teilmann J. (2006), Impacts of offshore wind farm construction on harbor porpoises: acoustic monitoring of echo-location activity using porpoise detectors (T-PODs). Marine Ecology Progress Series, 321, 295-308.

Castelo Branco N.A.A. and Alves-Pereira M. (2004), Vibrioacoustic disease, Noise \& Health, 6, 3-20.

Cowell R. (2010), Wind power, landscape and strategic, spatial planning: the construction of "acceptable locations" in Wales, Land Use Policy, 27, 222-232.

Danielson O. (1995), Viewpoint: large-scale wind power in Denmark, Land Use Policy, 12, 60-62.

Devine-Wright P. (2005), Beyond NIMBYism: towards an integrated framework for understanding public perceptions of wind energy, Wind Energy, 8, 125-139.

Drewitt A.L. and Langston R.H.W. (2006), Assessing impacts of wind farms on birds. Ibis, 148, 29-42.

EC (2000), The noise policy of the European Union-Year 2, Luxembourg. http://europa.eu.int/comm/environment/noise/pdf/noisebrochure.pdf.

EC (2001a), Directive 2001/77/EC of the European Parliament and the Council of 27 September 2001 on the promotion of electricity produced from renewable energy sources in the internal electricity market, Official Journal of the European Communities, 27.10.2001, L283/33.

EC (2001b), Directive 2001/42/EC of the European Parliament and of the Council of 27 June 2001 on the assessment of the effects of certain plans and programs on the environment, Official Journal L 197 , 21/07/2001 P.0030-0037.

EC (2007), The support of electricity from renewable energy sources. Communication from the Commission, COM 627 final, European Commission, December 7, Brussels.

Edkins M. (2008), Impacts of wind energy development on birds and bats: looking into the problem, FPL Energy. Also available at: www.eci.ox.ac.uk.

EEC (1992), Council Directive 92/43/EEC of 21 May 1992 on the conservation of natural habitats and of wild fauna and flora. OJ L 206, 22.7.1992, p.7.

EEC (1993), Council Decision of 25 October 1993 Concerning the Conclusions of the Convention on Biological Diversity, 93/626/EEC, Official Journal, L309, 13/12/1993.

Ek K. (2005), Public and private attitudes towards "green" electricity: the case of Swedish wind power, Energy Policy, 33, 1677-1689.

Ellis G., Barry J. and Robinson C. (2007), Many ways to say 'No', different ways to say 'Yes': applying Qmethodology to understand public acceptance of wind farm proposals, Journal of Environmental Planning and Management, 50, 517-551.

Eltham D.C., Harrison G.P. and Allen S.J. (2008), Change in public attitudes towards a Cornish wind farm: implications for planning, Energy Policy, 36, 23-33.

Etherington J. (2010), The Wind Farm Scam: an Ecologist's Evaluation, Stacy International, London, $198 p$.

Everaert J. and Stienen E.W.M. (2007), Impact of wind turbines on birds in Zeebrugge (Belgium), Biodiversity and Conservation, 16, 3345-3359.

EWEA (2011a), Wind Energy and EU Climate Policy: achieving 30\% lower emissions by 2020. A report by the European Wind Energy Association, October 2011.

EWEA (2011b), EU Energy Policy to 2050: achieving 80-95\% emission reductions. A report by the European Wind Energy Association, March 2011.

Firestone J. and Kempton W. (2007), Public opinion about large offshore wind power: underlying factors, Energy Policy, 35, 1584-1598.

Firestone J., Kempton W. and Krueger A. (2009), Public acceptance of offshore wind power projects in the USA, Wind Energy, 12, 183-202.

Fox A.D., Desholm M., Kahlert J., Christensen T.K. and Krag Petersen I.B. (2006), Information needs to support environmental impact assessment of the effects of European marine offshore wind farms on birds, In Wind, Fire and Water: Renewable Energy and Birds. Ibis 148 (Suppl. 1): 129-144.

Frantzis A. (1998), Does accustic testing strand whales?, Nature, 342, 29., 14-20.

Frantzis A. (2004), The first mass stranding that was associated with the use of active sonar (Kyparissiakos Gulf, Greece 1996). ECS Newsletter 42 (Special Issue)

Garthe S. and Huppop O. (2004), Scaling possible adverse effects of marine wind farms on seabirds: developing and applying a vulnerability index, Journal of Applied Ecology, 41, 724-734. 
Gee K. (2010), Offshore wind power development as affected by seascape values on the German North Sea coast, Land Use Policy, 27, 185-194.

Gordon J., Gillespie D., Potter J., Frantzis A., Simmonds M.P., Swift R. and Thompson D. (2003), A Review on the Effects of seismic Surveys on Marine Mammals, Marine Technology Society Journal, 37, 16-34.

Harding G., Harding P. and Wilkins A. (2008), Wind turbines, flicker and photosensitive epilepsy: characterizing the flashing that may precipitate seizures and optimizing guidelines to prevent them, Epilepsia, 49, 1095-1098.

Henderson A.R. (2002), Offshore Wind in Europe. Refocus, March/April, 14-17. Available at: www.refocus.net.

Henninger H.P. and Watson W.H. (2005), Mechanisms underlying the production of carapace vibrations and associated waterborne sounds in the American Lobster, Homarus americanus, Journal of Experimental Biology, 208, 3421-3429.

Huntley B., Collingham Y.C., Green R.E., Hilton G.M., Ranbeck C. and Willis S.G. (2006), Potential impacts of climate change upon geographical distribution of birds. In Wind, Fire and Water: Renewable Energy and Birds, Ibis 148 (Suppl. 1), 8-28.

Jay S.A. (2008), At the margins of planning: offshore wind farms in the United Kingdom, Ashgate, Aldershot.

Karydis M. and Kitsiou D. (2012), Environmental Marine Monitoring: matching science with policy, Submitted to Environmental Monitoring and Assessment (June 2012).

Karydis M. and Kitsiou D. (in press), Eutrophication and Environmental Policy in the Mediterranean Sea: a review. Environmental Monitoring and Assessment, DOI 10.1007/s10661-011-2313-2.

Keller A.C. (2009), Science in environmental policy. The MIT Press, Cambridge, Massachusetts.

Kempton W., Firestone J., Lilley J., Rouleau T. and Whitaker P. (2005), The offshore wind power debate: views from Cape Cod, Coastal Management, 33, 119-149.

Kitsiou D. and Karydis M. (2011), Coastal marine eutrophication assessment: a review on data analysis, Environment International, 37, 778-801.

Koschinski S. (2002), Current knowledge on the harbor porpoises (Phocoena phocoena) in the Baltic Sea, Ophelia, 55, 157-197.

Koschinski S., Culik B.M., Henriksen O.D., Tregenza N., Graeme E., Jansen C. and Kathe G. (2003), Behavioral reactions of free-ranging porpoises and seals to the noise of a simulated $2 \mathrm{MW}$ windpower generator, Marine Ecology-Progress Series, 265, 263-273.

Krause C.L. (2001), Our visual landscape managing the landscape under special consideration of visual aspects, Landscape and Urban Planning, 54, 239-254.

Krohn S. and Damborg S. (1999), On public attitudes towards wind power, Renewable Energy, 33(1), 111-118.

Ksentini F.Z. (1994), Final report: review of further developments in fields with which the sub-commission has been concerned: human rights and the environment. Commission on Human Rights, 6 July.

Kunz T.H., Arnett E.B., Cooper B.M. et al. (2007a), Assessing impacts of wind energy development on nocturnally active birds and bats: a guidance document, Journal of Wildlife Management, 71, 24492486.

Kunz T.H., Arnett E.B., Erickson W.P. et al. (2007b), Ecological impacts of wind energy development on bats: questions, research needs and hypotheses, Frontiers in Ecology and the Environment, 5, 315324.

Kuvlesky WP., Brennan L.A., Morrison M.L., Boydston K.K., Ballard B.M. and Bryant F.C. (2007), Wind energy development and wildlife conservation: challenges and opportunities, Journal of Wildlife Management, 71, 2487-2498.

Langston R.H.W. and Pullan J.D. (2003), Wind farms and birds: an analysis of the effects of wind farms on birds, and guidance on environmental assessment criteria and site selection issues, Report written by Birdlife International on behalf of the Bern Convention. Council Europe Report T-PVS/Inf.

Levington J.S. (2001), Marine biology: function, biodiversity, ecology. $2^{\text {nd }}$ Edition, Oxford University Press, Oxford.

Madsen P.T., Wahlberg M., Tougaard J., Lucke K. and Tyack P. (2006), Wind turbines underwater noise and marine mammals: implications of current knowledge and data needs, Marine Ecology Progress Series, 309, 279-295.

Mann D., Higgs D., Tavolga W., Souza M.J. and Popper A.N. (2001), Ultrasound detection by clupeiform fishes, The Journal of the Acoustical Society of America, 109, 3048-3054.

McLaren Loring J. (2007), Wind energy planning in England, Wales and Denmark: factors influencing project success, Energy Policy, 35, 2648-2660. 
Middleton N. (2008), The Global Casino: an introduction to environmental issues. Hodder Education, London.

Moller B. (2010), Spatial analyses of emerging and fading wind energy landscapes in Denmark, Land Use Policy, 27, Routledge Publ., London.

Morris P. and Therivel R., Eds. (2009), Methods of Environmental Impact Assessment, $3^{\text {rd }}$ Edition, Routledge Publ., London.

Nadai A. and Van der Horst D. (2010), Wind power planning, landscapes and publics, Land Use Policy, 27, 181-184.

Nowacek D.P. and Thorne L.H., Johsston D.W. and Tyack P.L. (2007), Responses of crustaceans to anthropogenic noise, Mammal Reviews, 37, 81-115.

Orum P., and Heminway D. (2005), Give the Public and Workers the Full Right-to-know and Participate. The Louisville Charter for Safer Chemicals, September.

Parsons E.C.M., Dolman S.J., Wright A.J., Rose N.A. and Burns W.C.G. (2008), Navy sonar and cetaceans: just how much does the gun need to smoke before we act?, Marine Pollution Bulletin, 56, 1248-1257.

Pasqualetti M.J. (2000), Morality, space and the power of wind-energy landscapes, Geographical Review, 90, 381-394.

Pedersen E. and Persson Waye K. (2004), Perception and annoyance due to wind turbine noise-a doseresponse relationship, Journal of the Acoustical Society of America, 116, 3460-3470.

Pedersen E. and Persson Waye K. (2007), Wind turbine noise, annoyance and self-reported health and well-being in different living environments, Occupational and Environmental Medicine, 64, 480-486.

Popper A.N., Plachta D.T.T., Mann D.A. and Higgs D. (2004), Response of clupeid fish to ultrasound: a review, ICES Journal of Marine Science, 61, 1057-1061.

REN21 (2009), Renewables Global Status Report 2009 Update, REN21, Secreteriat, Paris, 32pp.

Richardson W.J., Creen C.R.Jr, Malme C.I. and Thomson D.H. (1995), Marine mammals and noise, Academic Press, New York.

Richardson W.J., Miller G.W. and Greene C.R. (1999), Displacement of migrating bowhead whales by sounds from seismic surveys in shallow waters of Beaufort Sea, Journal of Acoustical Society of America, 106, 2281.

Ridder D. and Pahl-Wostl C. (2005), Participatory Integrated Assessment in local level planning, Regional Environmental Change, 5, 188-196.

Rosenquist K. (2012), Wind turbines need a separate noise standard. Post Bulletin, 24 April 2012. http://postbulletin.com/news.

Rotmans J. (1999), Integrated Assessment Models. Uncertainty, Quality and Use. ICIS Working paper 199-E005, Maastricht.

Smedley A., Webb A.R. and Wilkins A. (2010), Potential of wind turbines to elicit seizures under various meteorological conditions, Epilepsia, 51, 1146-1151.

Soderholm P., Ek K. and Petterson M. (2007), Wind power development in Sweden: Global policies and local obstacles, Renewable and Sustainable Energy Reviews, 11, 365-400.

Still D. (2001), Offshore wind at Blyth, Renewable Energy, 24, 545-551.

Therivel R. (2009), Noise. In: Morris, P. and Therivel, Eds., R. (2009), Methods of Environmental Impact Assessment. $3^{\text {rd }}$ Edition, Routledge Publ., London.

Todd N.R.M., Rosengren S.M. and Colebatch J.G. (2008), Tuning and sensitivity of the human vestibular system to low frequency vibration, Neuroscience Letters, 444, 36-41.

Toke D. (2002), Wind power in UK and Denmark: can rational choice help explain different outcomes?, Environmental Politics, 33, 1527-1539.

Toke D. (2005), Explaining wind power planning outcomes: some findings from a study in England and Wales, Energy Policy, 33, 1527-1539.

UKERC (2006), The costs and impacts of intermittency (UK Energy Research Center).

Van der Horst D. (2007), NIMBY or not? Exploring the relevance of location and the politics of voiced opinions in renewable energy siting controversies, Energy Policy, 35, 2705-2714.

Van der Horst D. and Toke D. (2010), Exploring the landscape of wind farm developments; local area characteristics and planning process outcomes in rural England, Land Use Policy, 27, 214-221.

VisitScotland (2003), Investigation into the Potential Impact of Wind Farms on Tourism in Scotland.

Walker G. (1995), Renewable energy and the public, Land Use Policy, 12, 49-59.

Warren C.R., Lumsen C., O'Dowd S. and Birnie R.V. (2005), Green on green: public perceptions of wind power in Scotland and Ireland, Journal of Environmental Planning and Management, 48, 853-875.

Weilgart L.S. (2007), The impacts of anthropogenic ocean noise on cetaceans and implications for management, Canadian Journal of Zoology, 85, 1091-1116. 
WHO (1999), Guidelines for Community Noise. Berglund B., Linvall T. and Schwela D.H. (Eds.), Word Health Organization.

William W. (2004), When Blade Meets Bat. Scientific American, February 2004.

WIND Engineers, Inc. (2003), Shadow flicker modeling. www.efsec.wa.gov/.../E09 Shadow

Wolsink M. (1989), Attitudes and expectancies about wind turbines and wind farms, Wind Engineering, 13, 196-206.

Wolsink M. (1994), Entanglement of interests and motives: assumptions behind the NIMBY theory on facility siting, Urban Studies, 31, 851-866.

Wolsink M. (2000), Wind power and the NIMBY myth: institutional capacity and the limited significance of public support, Renewable Energy, 21, 49-64.

Wolsink M. (2007), Planning of renewable schemes: deliberative and fair decision-making on landscape issues instead of reproachful accusations of non-cooperation, Energy Policy, 35, 2692-2704.

Wolsink M. (2010), Near-shore wind power-protected seascapes, environmentalist's attitudes and the technocratic planning perspective, Land Use Policy, 27, 195-203.

Wursig B., Greene C.R. and Jefferson T.A. (2000), An air bubble curtain reduces noise of percussive piling to protect dolphins, Marine Environmental Research, 49, 79-93.

WWEA (2008), 2008-last update, world wind energy association. Available at: http://www.wwindea.org/home/index.php?option 